\title{
ADVERSE EVENTS IN HEALTH AND NURSING CARE: PATIENT SAFETY FROM THE STANDPOINT OF THE PROFESSIONAL'S EXPERIENCE
}

\author{
Augusto Ferreira Umpiérrez', Zoraida Fort Fort², Virginia Chiminelli Tomás ${ }^{3}$
}

\footnotetext{
${ }^{1}$ Ph.D. in Nursing. Full Professor, Universidad Católica del Uruguay. Montevideo, Uruguay. E-mail: auferrei@ucu.edu.uy

2 Ph.D. in Nursing. Associate Professor, Universidad Católica del Uruguay. Montevideo, Uruguay. E-mail: zfort@ucu.edu.uy

${ }^{3}$ Nursing Degree. Health Management Specialist. Adjunct Professor, Universidad Católica del Uruguay. Montevideo, Uruguay.

E-mail: virchiminelli@gmail.com
}

\begin{abstract}
The aim of the present study was to acknowledge the significant aspects brought about by nurses regarding their experience of being responsible for the occurrence of health adverse events. This exploratory qualitative study employed a hermeneutic dialectic approach. The sample comprised 10 nurses who had been responsible for the occurrence of an adverse event at least once and four nursing supervisors with oversight responsibility for patients at the time the adverse events occurred. Analysis of the collected data allowed for the construction of analysis categories. Relevant issues regarding the need to empower human resources and strengthen recruitment systems were identified, with emphasis to the lack of personnel, workload, teamwork, and continuing education. Results allow for the visualization of an opportunity to put interventions into practice, aiming at contributing to a safer care system.
\end{abstract}

DESCRIPTORS: Patient safety. Nursing care. Nursing staff. Quality of health care.

\section{EVENTOS ADVERSOS NA SAÚDE E OS CUIDADOS DE ENFERMAGEM: A SEGURANÇA DOS PACIENTES DESDE A EXPERIÊNCIA DO PROFISSIONAL}

RESUMO: O estudo tem como objetivo conhecer os aspectos significativos apresentados pelas enfermeiras acerca da experiência de ter sido responsáveis por um evento adverso de saúde. Estudo qualitativo, com enfoque hermenêutico dialético. Amostra de 10 enfermeiras que tiveram ao menos uma experiência de responsabilidade perante um evento adverso e 4 supervisores de enfermagem, com responsabilidade da supervisão ao ocorrer o evento. A análise dos dados coletados permitiu construir categorias de análise relacionadas às necessidades de recursos humanos. Identificaram-se aspectos relevantes respeito à necessidade de fortalecer o sistema de recursos humanos, com dimensionamento de carga de trabalho, o trabalho em equipe, a formação do pessoal, como questões importantes para os enfermeiros. Os dados resultantes permitem enxergar um caminho para pôr em prática intervenções orientadas a colaborar com um sistema seguro de atendimento.

DESCRITORES: Segurança do paciente. Cuidados de enfermagem. Recursos humanos de enfermagem. Qualidade da assistência à saúde.

\section{EVENTOS ADVERSOS EN SALUD Y CUIDADOS DE ENFERMERÍA: LA SEGURIDAD DEL PACIENTE DESDE LA EXPERIENCIA DEL PROFESIONAL}

\begin{abstract}
RESUMEN: El estudio tuvo como objetivo conocer los aspectos significativos que surgen de las enfermeras acerca de la experiencia de haber sido responsables de un evento adverso en salud. Estudio cualitativo, con enfoque hermenéutico dialéctico. Muestra de 10 enfermeras que tuvieron al menos una experiencia de responsabilidad ante un evento adverso y cuatro supervisores de enfermería con responsabilidad de supervisión al ocurrir el evento. El análisis de los datos recogidos permitió construir categorías de análisis relacionadas con las necesidades de recursos humanos. Se identificaron aspectos relevantes respecto a la necesidad de fortalecer el sistema de recursos humanos y su selección, surgiendo la dotación de personal, la carga de trabajo, el trabajo en equipo y la formación permanente como aspectos significativos para las enfermeras. Los datos emergidos permiten visualizar un camino para poner en práctica intervenciones tendientes a colaborar con un sistema seguro de atención.
\end{abstract}

DESCRIPTORES: Seguridad del paciente. Cuidados de enfermería. Personal de enfermería. Calidad de la atención de salud. 


\section{INTRODUCTION}

One of the major goals of healthcare quality, a major concern for sanitary systems nowadays, is the patient safety, as pointed out by the World Health Organization. ${ }^{1}$ Several aspects related to this issue, such as the organizational context, diagnostic techniques, an environment and a culture of safety, and healthcare-based human resources stand out as quite relevant issues to be addressed. These aspects are all links of a chain that may ultimately generate damages to patients receiving sanitary care. In a healthcare team, nursing professionals are very closely related and directly connected with patients. In this sense, the design of a nursing plan should presuppose that specific risks surrounding each patient, as well as the organizational context in which health professionals work, are taken into account. ${ }^{2}$

For this reason, given the relevance of the nursing human resource in sanitary services, the perception of professionals and the meanings they assign to their service become quite a significant study object. The perspective of those who render the service should draw the attention of researchers concerned about patient safety. ${ }^{3}$ Aligned with these thoughts, some studies show a growing number of nurses committed to the creation of safer systems, taking over leading positions toward providing patients with risk-free quality care. ${ }^{4}$

In Uruguay, authorities are constantly concerned about the safety of patients. Nonetheless, the country still lacks comprehensive research in this area. Hence, we can affirm that the generation of contextualized knowledge in this area allows for the exploration, comprehension and dissemination of results. Combined with other studies, such results will be crucial toward correct decision-making processes.

Bearing this in mind, the aim of the present study was to acknowledge the significant aspects brought about by nurses regarding their experience of being responsible for the occurrence of health adverse events.

\section{METHODOLOGY}

In face of the need for more deeply understand the experience of nursing professionals regarding adverse events, the authors of the present research decided to undertake a qualitative study, as this methodology allows researchers to acknowledge the perceptions, expectations and feelings of those undergoing such singular situa- tions. ${ }^{5}$ The study employed a dialectic hermeneutic approach by means of the content analysis, ${ }^{6}$ which takes into account the context in which nurses carry out their functions.

Hermeneutics is focused on the interpretation of historically located events, and considers historicity, tradition and authority as determining elements toward the comprehension of any given phenomenon. The employed interviews allowed for a better interpretation of the convergences and divergences produced by the statements of the subjects. ${ }^{7}$ Such emphasis generated the understanding of their historical achievements, daily life and reality itself. ${ }^{8}$ The dialectical hermeneutics established a critical attitude toward assessed objects, thus reflecting real correlations. As it comprehends and analyzes each part of the whole picture, such methodology allows reality to be seen as an integrated whole, and hence generates more concrete correlations between specific information units and the whole set of information, ${ }^{9}$ thus turning patient safety and the human resources involved into special reference points. The contribution of the interpreter is a critical step toward the comprehension of the assessed event. ${ }^{10}$

Therefore, samples subjects for this study were searched considering a totalizing, integrating perspective. The sample was composed of 10 nurses that carried out their services at second and third level healthcare institutions in Montevideo. These selected nurses had had at least one event in which they experienced an adverse event in the previous two years. Finally, four nurses in charge of supervising the nursing service at the time an adverse event occurred were also part of the study. The selection of subjects and their rich experiences related to this issue were based on a search criterion that added significant relevance to the study. The research defined the limit of participants when all inquiries of the researchers were fully responded. ${ }^{11}$

The data collection process was carried out by means of in-depth interviews that lasted for approximately 90 minutes each. The interviews were performed in a reserved space, making it easier for participants to open up. The study's guiding questions were defined in a way to extract the most effective data, trying to prevent any sort of previous orientation whatsoever. This process occurred between November and December 2012. All interviews were recorded in order to be fully transcribed later by the researcher. Each interview was identified by a letter and a sequenced number ( $\mathrm{N}$ for nurse and $\mathrm{S}$ for supervisor), in a way 
to maintain the anonymity of the participants. The subjects agreed with the interviews, and the researcher guaranteed anonymity, privacy and confidentiality of the rendered information. All ethical issues regarding research with human subjects established by the country's decree number $379 / 008^{12}$ were complied with, and participants were informed on the objectives and the reach of the study. All aspects related to the free and informed consent were agreed between both parts. The study was authorized by the Ethics Advising Committee of the Nursing and Health Technologies Faculty of the Catholic University of Uruguay under protocol number 008-2013.

In terms of the use of the content analysis as a data analysis process, such method allows for the study of contents in a given context, as well as for the interpretation of resulting materials. ${ }^{13}$ In this sense, data were analyzed in compliance with the history of the organization, classification order and final analysis, which generated common sense groups. The careful, thorough reading of each interview generated the following results: the apprehension of the global meaning of the experience of each subject; the organization of meaningful aspects into group categories, aiming at producing common sense clusters; the constitution of concrete categories, named in such a way that they could represent the addressed issue; the construction of each category; analysis of each category, seeking the real experience expressed by nurses and supervisors; and the discussion about the results in the light of the elected methodology and all produced evidences.

\section{RESULTS}

Comprehensive analysis of the interviews based on the dialectical hermeneutics allowed for the emergence of significant aspects related to the experiences of the nurses in face of their responsibility for the occurrence of a health adverse event, which led the present study to come up with a set of issues related to nursing human resources. Such approach constituted the following categories: lack of personnel, workload, teamwork, and continuing education.

In the 'lack of personnel' category, subjects affirmed that the number of professionals working at the time the adverse event occurred was insufficient. Both nurses and supervisors clearly expressed that the lack of personnel directly influenced the emergence of adverse events, according to the following statements:
[...] me and the supervising nurse were on our own in the ward that day, two of our colleagues did not show up and were not replaced. Then, I was the whole day in a rush and something would certainly go wrong at any time (N2).

[...] I knew something was going to happen. When I started my shift, there were people lacking, and we did not have any replacement. I tried to organize myself in order to help my colleague in the ward, which had more patients that day, but when I was finally able to get there, half of the shift had already gone, the assisting nurse was new in the job and she had administered an injection to the wrong patient (S1).

The 'workload' category is directly related to the previous one, as a result of personnel deficit. Each statement points out an overload of work at the time the mistaken action took place. The interviewed nurses and supervisors affirm that:

[...] there were lots of work to be done, I felt totally alone, I was just not able to do everything at a time. I rushed up and down. It's not like that every day, it's a nice work environment here, but some shifts just surmount lots of work, because of the absences. Our colleagues are often absent and in the end those who come to work end up being overloaded, and sooner or later we'll make mistakes (N6).

[...] I just can't stand the idea of coming through it all once again, I felt terrible, but the reason is that I was utterly overloaded. I told them several times, I insisted that I would not bear it all for much longer, but...(N8).

[...] I believe it happened because she had lots of work to do, she had so many things to do and there were only two people in the whole ward. We don't have many patients, because our ward has only a few beds. The problem is that we lacked personnel (S2).

Analysis of the interviews showed that both supervisors and nurses affirmed that teamwork becomes a strong aspect when lack of personnel emerges. They also pointed out the negative relevance of workload. Moreover, they highlight that the team's communicational process, as well as the promptness of each nurse to help others in the work environment, positively affect the services rendered to patients. Hence, the 'teamwork' category emerged:

[...] I would have made a thousand mistakes if it weren't for my team. Despite the inconveniences, it's such a pleasure to work with them. Above all, when a patient comes to your ward and your colleague from another department helps you out, or transfers the shift with everything all set. Teamwork is undoubtedly quite a support for us (N4). 
[...] I'm committed to support direct care processes, it's a priority for me over the massive paperwork that usually overloads us. The teamwork produced by the technical personnel, managers and supervisors stands out as something valuable here. Problems come and go, but where there is a good communication process going on, there is always an opportunity to improve (S2).

The interviews show how clearly nurses and supervisors highlight the 'continuing education' category as a special factor to be taken into account. This category was expressed in the following way:

[...] the fact is that I just did not know what to do. These things are quite rare in your career, nobody tells you what to do when things go wrong, or if they say you hardly incorporate it (N6).

[...] They organized a workshop on patient safety, but in my opinion there's so much more that needs to be done, things that you can be reminded of every single day. Then, when these things happen again, and I wish they don't, you are more prepared, more aware of what to do (N9).

[...] I insist and will keep insisting that they have to train you on this issue. I already have a project to implement in my shift, but it should be replicated in the entire hospital (S3).

\section{DISCUSSION}

Analysis of the interviews allowed for the construction of the aforementioned categories, and revealed some aspects to be interpreted and discussed in the light of other studies concerning this issue.

One of the major emerging issues was related to the lack of personnel. Such information matches the findings from other authors and reinforces the evidence that the lack of nursing professionals directly influences the safety of patients.,14 Obviously, the lack of personnel shapes the number of patients to be cared for per nurse. Such standard reverberates in service and care management processes, and should be counted among the initiatives toward more effective care responsibility. ${ }^{15}$

In connection with this issue, this study observed the excessive workload of the nurses at the time adverse events occurred. In several cases, daily problem-solving practices, such as multitask demands resulting from the lack of quantity and quality of resources - a characteristic that matches the findings from other authors - consequently brought about various shortcomings in the work processes. ${ }^{16}$ As it has been shown, the implementation of comprehensive nursing processes generates very positive results toward the safety of patients, as they can assess and detect potential risks. ${ }^{17} \mathrm{In}$ face of the lack of numbers and quality of professionals, excessive workloads and unfavorable conditions experienced by the nurses obviously restricts the implementation of an adequate healthcare management. Sometimes, the response to the lack of personnel is only focused on increasing the number of professionals, thus leaving aside the quality of the health care these professionals are able to render.

In spite of these facts, bearing in mind the previously mentioned difficulties, an important element should be taken into account by nursing managers: teamwork provides a powerful support to professionals. The communication among service personnel, as well as their communication with professionals from other services, stand out as a relevant mechanism toward coping with adverse events, and finally toward the diminishment of failures, a fact that also complies with the results of other studies on this issue. ${ }^{18}$ These findings call for the establishment of a safety network, where the organizational environment and the openness to horizontal dialogues ${ }^{19}$ involving managers, technicians and even patients and their families are envisioned as potential actions toward the generation of safer sanitary health environments. ${ }^{20}$

Another important aspect observed by this study was related to the permanent training of human resources. Indicators show a shortage of both undergraduate courses and continuing education programs. The competences of nursing professionals directly affect the safety of patients and the generation of risk-free care processes, a consistent fact with the findings from other researchers who focused on this issue. ${ }^{21}$ Professional and personal competences are doorways to safe care..$^{22}$ As such, it is very important that this aspect of the academic background of professionals be taken very seriously by those in charge of planning and designing care services.

This study agrees with other researchers who point out that continuing education processes and the effective qualification of professionals enable safer practices, thus preventing damages and minimizing risks derived from sanitary care. ${ }^{23} \mathrm{In}$ this sense, directors of healthcare services should encourage nurses to advance their knowledge and professional skills. ${ }^{24}$ 
The results of this research allow us to envision relevant aspects of the nursing practice both concerning more complex dimensions - such as the increase in the number of personnel and the diminishment of workload in a sanitary system that lacks human resources within an unattractive national and international context -, and at the same time other simpler, more easily implemented dimensions - such as the encouragement of teamwork and the academic and professional improvement of workers. Various examples and models designed to improve communication, responsibility, teamwork, and leadership focus on safety and quality improvement, among others, and may be taken as starting points toward ensuring that patients are the center of healthcare services. ${ }^{25}$

The aspects addressed here stand out as part of a safety culture that should permeate institutions and sanitary processes, aiming at becoming essential requirements toward strongly preventing the emergence of adverse events and generating proactive learning processes that may generate good practices. The safety culture allows for the generation of virtuous cycles aimed at designing systems in which past mistakes are prevented from happening again.

Several aspects related to the safety of patients were addressed by the present study. However, this research does not intend to generalize its results, as its focus hits the in-depth approach of singularities observed in the participants involved in an adverse event. In any case, the results originated from the gathered data enlighten a way toward broadening this issue and transforming theory into a practice that may contribute toward a safety culture in the sanitary healthcare, bringing about several positive implications to the practice and the professional qualification of nurses.

\section{FINAL CONSIDERATIONS}

This study identified relevant aspects regarding the need for strengthening the human resource system of the nursing practice, as well as its selection process. The nurses highlighted the emergence of categories such as lack of personnel, workload, teamwork, and continuing education of professionals as quite significant aspects. Related data allow for the visualization of a pathway toward the practice of health interventions aimed at collaborating with a safer care system.

In order to contextualize evidences, further studies should be carried out, so that new knowl- edge on such a complex issue - patient safety - is generated, aiming at solving complex problems. Concurrently, such initiatives also encourage each service to start developing the model addressed by this study in their daily practice, thus contributing to the quality of sanitary care.

\section{REFERENCES}

1. World Health Organization/World Alliance for Patient Safety. Summary of the evidence on patient safety: implications for research. The Research Priority Setting Working Group of the World Alliance for Patien Safety. Geneva: World Health Organization; 2008.

2. Gomez A, Espinosa A. Dilemas éticos frente a la seguridad del paciente: cuidar es pensar. Rev Aquichán. 2006 Oct; 6(1):54-67.

3. Lake E, Shang J, Klaus S, Dunton N. Patient falls: association with hospital magnet status and nursing unit staffing. Res Nurs Health. 2010 Oct; 33(5):413-25.

4. Martínez AA, Hueso C, Gálvez G. Fortalezas y amenazas en torno a la seguridad del paciente según la opinión de los profesionales de enfermería. Rev Latino-Am Enfermagem. 2010 Mai-Jun; 18(3):42-9.

5. Prado M do, Souza M de, Carraro T. Investigación cualitativa en Enfermería: contexto y bases conceptuales. Washington D. C. S: OPS; 2008.

6. Campos J, Turato E. Content analysis in studies using the clinical-qualitative method: application and perspectives. Rev Latino-Am. Enfermagem. 2009 Mar-Apr; 17(2):259-64.

7. Remor C, Remor L. A entrevista: fundamentos da hermenêutica e da psicanálise. Texto Contexto Enferm [online]. 2012 Dec [acesso 2014 Mar 10]; 21(4):963-70. Disponível em: http://www.scielo. br / scielo.php?script=sci_arttext\&pid=S010407072012000400029\&lng=en

8. Minayo MCS. O desafio do conhecimiento. Pesquisa qualitativa em saúde. São Paulo (SP): Hiucitec; 2010.

9. Minayo MCS. Hermenêutica - dialética como caminho do pensamento social. En: Minayo MCS, Deslandes SF, organizadores. Caminhos do pensamento: epistemologia e método. Rio de Janeiro (RJ): Editora Fiocruz; 2002.

10. Cortés N. Descaminhos do método: notas sobre historia e tradicao em Hans-George Gadamer. Varia Hist. 2006; 22(36):274-90.

11. Arias MM, Giraldo CV. Scientific rigor in qualitative research. Invest Educ Enferm. 2011 Nov; 29(3):500514.

12. Uruguay. Decreto de Ley n. 379/008. Investigaciones con seres humanos. Diario Oficial $n^{\circ} 4573 / 08$, diciembre de 2008. 
13. Lessard-Hérbert M, GoyetteG, Boutin G. Investigação cualitativa, fundamentos e prácticas. $4^{\mathrm{a}} \mathrm{ed}$. Portugal: Stória Editores, Instituto Piaget; 2010.

14. Gómez O, Arenas W, González L, Garzón J, Mateus Erika, Soto A. Cultura de seguridad del paciente por personal de enfermería en Bogotá, Colombia. Cienc Enferm. 2011 Dic; 17(3):97-111.

15. León C. La seguridad del paciente, una responsabilidad en el acto del cuidado. Rev Cubana Enfermer. 2006 Sep; 22(3):1-7.

16. Mello J, Barbosa S. Cultura de segurança do paciente em terapia intensiva: recomendações da enfermagem. Texto Contexto Enferm. 2013 Dec [acesso 2014 Mar 10]; 22(4):1124-33. Disponível em: http:/ / www.scielo.br/scielo.php?script=sci_ arttext\&pid=S0104-07072013000400031

17. Abaunza M. Is the nursing process part of quality care? Av Enferm. 2007 Dec; 26(1):141-7.

18. Campbell EG, Singer S, Kitch BT, Iezzoni LI, Meyer GS. Patient safety climate in hospitals: act locally on variation across units. Jt Comm J Qual Patient Saf. 2010 Jul; 36(7):319-26.

19. Škodová M, Velasco Rodríguez MJ, Fernández Sierra MA. Opinión de los profesionales sanitarios sobre seguridad del paciente en un hospital de primer nivel.
Rev Calidad Asistencial. 2011 Ene-Feb; 26(1):33-8.

20. Aranaz-Andrés JM, Aibar-Remón C, LimónRamírez R, Amarilla A, Restrepo FR, Urroz O, et al. Prevalence of adverse events in the hospitals of five Latin American countries: results of the 'Iberoamerican study of adverse events' (IBEAS). BMJ Qual Saf. 2011 Jun; 20(12):1043-51.

21. Urbina O. Competencias de enfermería para la seguridad del paciente. Rev Cubana Enfermer. 2011 Jul-Sep; 27(3):239-47.

22. Agramonte A, Farres R. Influencia del desarrollo de la personalidad profesional durante la carrera de enfermería en la seguridad del paciente. Rev Cubana Enfermer. 2011 Ene-Mar; 27(1):8-15.

23. BreaP, Almuedo A, Rojas deMora A, Torres A. Buenas prácticas que promueven la seguridad. Desempeño profesional de las enfermeras acreditadas. Rev Enferm. 2011 Jul-Ago; 34(7/8):525-30.

24. Teng CI, Shyu YI, Dai YT, Wong MK, Chu TL, Chou TA. Nursing accreditation system and patient safety. J Nurs Manag. 2012 Apr; 20(3):311-8.

25. Morris F. Assessment and accreditation system improves patient safety. Nurs Manag (Harrow). 2012 Nov; 19(7):29-33. 